\title{
Impact of the herbicide metolachlor on river periphytic diatoms: Experimental comparison of descriptors at different biological organization levels
}

\author{
Vincent Roubeix*, Nicolas Mazzella, Brigitte Méchin, Michel Coste and François Delmas \\ Cemagref, UR REBX, 33612 Cestas Cedex, France
}

Received 19 November 2010; Accepted 8 March 2011

\begin{abstract}
A microcosm experiment was carried out in order to test the effect of the herbicide metolachlor on river periphytic diatoms and to find potential diatom bioindicators of contamination. Effects were investigated at different biological organization levels (biofilm, diatom community, population and individual levels). The colonization of glass substrates by natural biofilm in artificial streams did not vary quantitatively between control and contaminated conditions (5 and $30 \mu \mathrm{g} . \mathrm{L}^{-1}$ ). However, non-parametric multivariate analysis of variance revealed a significant difference between contaminated and control diatom communities with regard to species composition. The difference was due to the greater development of probably tolerant species in the presence of the herbicide (e.g., Planothidium frequentissimum, Planothidium lanceolatum, Amphora montana, Surirella brebissonii and Nitzschia gracilis). An increase in the occurrence of abnormal forms was observed in relation to metolachlor concentration. In particular, up to $8 \%$ of the frustules of the species Surirella angusta exhibited prominent deformities. Monospecific acute toxicity tests were then performed on two species to estimate toxicity parameters based on growth inhibition. These tests also confirmed the teratogenic effect of the herbicide on S. angusta. This study shows that low concentrations of metolachlor in natural streams may significantly alter diatom community structure and that abnormal diatom forms should be taken into account in water contamination assessment.
\end{abstract}

Key words: Community / diatoms / herbicide / metolachlor / toxicity

\section{Introduction}

Metolachlor (metolachlor) is a herbicide that belongs to the chloroacetanilide class that has replaced triazines to become one of the most frequently occurring groups of herbicides in the French surface waters survey networks (Dubois et al., 2010). It is commonly used before and after crop emergence to prevent weed growth (Kegley et al., 2010). The concentration of metolachlor in rivers is highly variable, peaking during the field application period and after heavy rain. Time-weighted concentrations of over $1 \mu \mathrm{g} . \mathrm{L}^{-1}$ were recorded in some rivers and peak concentrations reached several tens of $\mu \mathrm{g} . \mathrm{L}^{-1}$ (Battaglin et al., 2000; Clark and Goolsby, 2000; Dubois et al., 2010; Roubeix et al., 2010). Since agricultural pesticides contaminate rivers via runoff and spray drift, it has become essential to evaluate their impact on non-target aquatic organisms.

\footnotetext{
*Corresponding author: vincent.roubeix@cemagref.fr
}

Herbicides contaminating rivers may be particularly toxic to aquatic plants and algae. In shallow rivers, periphytic diatoms are often the dominant group of primary producers; they are at the basis of the trophic food web and any alteration of their communities may have repercussions at higher trophic levels. Diatoms are key factors for water quality evaluation in the European Water Framework Directive (European Commission, 2000). A good ecological status is attributed to rivers where the species composition of periphytic diatom communities is only slightly altered by human activities (Hering et al., 2010). The toxicity of metolachlor has been assessed via monospecific toxicological tests on microalgae (Fairchild et al., 1997; Ma and Liang, 2001; Junghans et al., 2003; Ma et al., 2003) but rarely with diatoms (Battaglin et al., 2000). Such tests, based on a single species and focusing on one endpoint (biomass production), only give partial information about the potential impact of the herbicide in the environment. Although it is not yet a standard method, testing microalgal communities sampled in the field assesses toxic 
effects on the individual species as well as on the whole assemblage.

Communities increase their tolerance to toxicants through two mechanisms: (i) development of tolerant and competitive species and reduction of the relative abundance of sensitive species (Schmitt-Jansen and Altenburger, 2005; Pesce et al., 2010) and (ii) tolerance acquisition of some species to toxic pressure (Ivorra et al., 2002). As diatoms are useful bioindicators of river eutrophication and saproby (Prygiel et al., 1999), there have been many attempts to find specific indicators of toxic pollution in diatom communities. Some field studies have tried to relate periphytic diatom community variations to herbicide concentrations; however, the variations in the field of many interfering factors (e.g., trophic level, shading and current velocity) make the isolation and clear demonstration of the toxic effect difficult (Morin et al., 2009; Roubeix et al., 2010). The experimental exposure of diatom communities to a chosen toxicant in enclosed controlled systems is then a suitable complementary approach. A large set of examples can be found in the literature with various herbicide molecules tested in either mesocosms or microcosms (Kosinski, 1984; Hamala and Kollig, 1985; Noack et al., 2003; Schmitt-Jansen and Altenburger, 2005; Mohr et al., 2008; Ricart et al., 2009; Vera et al., 2010).

In this study, microcosm experiments were designed to evaluate the effect of metolachlor on river periphytic diatoms. The objectives were (i) to assess the potential impact of water contamination on diatoms through different endpoints at different biological organization levels and (ii) to find potential indicators among diatoms of pollution by such a herbicide. In order to do this, an experiment using artificial channels was performed to explore the impact of the herbicide on diatom communities grown from river biofilm. Then, the response to metolachlor exposure of single species composing the communities was assessed via acute toxicological tests using the same descriptors as for the channel experiment to better understand the results obtained with complex assemblages.

\section{Material and methods}

\section{Experimental design}

\section{Artificial channels}

Natural diatom communities were collected in rivers by scraping immerged substrates with a scalpel and were maintained in bottled commercial spring water until return to the lab. The diatoms were sampled at four stations located on three small rivers in SW France (the Gèze, Sousson and Save, "Coteaux de Gascogne") with different exposures to agricultural pollution to obtain maximal species diversity. The upstream station on the Gèze River (Organ, $43.273^{\circ} \mathrm{N} 0.483^{\circ} \mathrm{E}$ ) and the station on the Save River (Montmaurin, $43.230^{\circ} \mathrm{N} 0.654^{\circ} \mathrm{E}$ ) were only slightly impacted by agricultural pollution, whereas significant pesticide concentrations were found at the downstream station on the Gèze River (Peyret, $43.327^{\circ} \mathrm{N} 0.535^{\circ} \mathrm{E}$ ) and at the station on the Sousson River (Aujan, $43.380^{\circ} \mathrm{N}$ $0.505^{\circ} \mathrm{E}$ ) (Roubeix et al., 2010).

The diatom samples were mixed before equal inoculation into six glass flasks ('artificial channels') filled with $40 \mathrm{~L}$ of filtered river water (Whatman GF/B filters, $1 \mu \mathrm{m}$ pore size) from the station with the highest water quality (Organ). In each channel, clean glass slides $(6 \times 10 \mathrm{~cm})$ were hung from the surface to mid depth and served as substrate for diatom colonization. An immerged pump (NEW-JET 2300) maintained a surface current between the glass slides, and daylight neon lamps placed over each channel gave a homogeneous illumination of $150 \mu \mathrm{mol} . \mathrm{m}^{-2} \cdot \mathrm{s}^{-1}$ with a 14:10 light-dark cycle. The surface turbulence created by the pumps ensured efficient oxygenation of the growth medium, which remained $\mathrm{O}_{2}$ saturated during the experiment. The filtered river water was slightly enriched with nutrients following the composition of WC culture medium (Guillard and Lorenzen, 1972), providing oligotrophic growth condition comparable to the study zone (Roubeix et al., 2010).

Racemic metolachlor $(98 \%$, Dr. Ehrenstorfer, Germany) was dissolved in ultrapure water at $100{\mathrm{mg} . \mathrm{L}^{-1}}^{-1}$ and an increasing volume of the solution was poured into the channels; this gave two controls (no metolachlor), two channels at $5 \mu \mathrm{g} . \mathrm{L}^{-1}$ and two others at $30 \mu \mathrm{g} . \mathrm{L}^{-1}$. In the following, the six channels are called $0 \mathrm{a}, 0 \mathrm{~b}, 5 \mathrm{a}, 5 \mathrm{~b}, 30 \mathrm{a}$ and $30 \mathrm{~b}$, the number corresponding to metolachlor concentration and the letters "a" or " $b$ " to the duplicate channels for each concentration.

Phosphate concentration was checked every two days and after each diatom sampling. Nutrient consumption by algae was compensated by the addition of concentrated WC medium in the proportion of the loss of $\mathrm{PO}_{4}$. At the same frequency, $10 \mathrm{~mL}$ water samples were taken at the surface of channels 5 and 30 for control of metolachlor concentrations along the time course of the experiment. These samples were filtered with Spartan RC 30 syringe filters $(0.45 \mu \mathrm{m}$, regenerated cellulose, Whatman) and stored in glass bottles at $4{ }^{\circ} \mathrm{C}$ until HPLC-ESI-MS/MS analysis. Two additional samples were taken from the control channels at the end of the experiment to check if there had not been any contamination. After one week of growth, a few millilitres of concentrated metolachlor solution was added to channels 5 and 30 to maintain concentration levels. Water temperature was measured daily at different hours of the day and averaged out at $21^{\circ} \mathrm{C}( \pm 2.4$ S.D., $n=27$ ). The loss of water volume by evaporation or sampling was compensated daily by addition of distilled water.

Biofilm samples were taken after two weeks of colonization from two glass slides. Glass slides were scraped with a cutter blade on both sides and the biofilm was resuspended in $200 \mathrm{~mL}$ of commercial spring water. From this suspension, $5 \mathrm{~mL}$ was kept in a $5 \%$ formaldehyde solution for diatom community examination and the rest was filtered on two Whatman $\mathrm{GF} / \mathrm{F}$ filters for dry 
mass and chlorophyll- $a$ measurements. After one week and following diatom sampling, $0.5 \mathrm{~L}$ water samples were taken from each channel for chemical analysis.

\section{Monospecific tests}

The species Surirella angusta and Achnanthidium minutissimum were isolated by V. Roubeix from the Gèze (from station Organ, see above) and the Ruiné Rivers (from a little polluted site: $45.4907^{\circ} \mathrm{N}, 0.0172^{\circ} \mathrm{E}$ ), respectively, in summer 2009. These two species were chosen because they are common in the studied area and because they showed contrasting responses to exposure to metolachlor in the channel experiments (see Results). Moreover, focusing on the species $S$. angusta allowed a more specific study of the relationship between metolachlor concentration and frustule deformation. The two diatoms were maintained in the same water as used for the artificial channels, enriched with nutrients from WC culture medium (with silicate). This growth medium was used to dissolve the racemic metolachlor and to dilute the concentrated solution $\left(100 \mathrm{mg} . \mathrm{L}^{-1}\right)$ to yield five test concentrations ranging from 30 to $38880 \mu \mathrm{g} . \mathrm{L}^{-1}$ on a logarithmic scale with a factor 3 . These concentrations were chosen to encompass the highest concentration tested in the channel experiment and concentrations at which the effect of metolachlor on diatom growth is visible. Concentrations were checked at this step by HPLC analysis. For each species, 15 autoclaved $50 \mathrm{~mL}$ glass bottles were filled with $30 \mathrm{~mL}$ of the obtained metolachlor solutions in triplicate plus five control bottles with metolachlor-free growth medium. Then, $1 \mathrm{~mL}$ of preconditioned exponentially growing culture was added to the bottles, which were placed on a rotative disk in a culture chamber at $23^{\circ} \mathrm{C}$ with a $130 \mu \mathrm{mol} . \mathrm{m}^{-2} . \mathrm{s}^{-1}$ illumination and a 14:10 light-dark cycle. Diatom biomass in the bottles was estimated by in vivo fluorescence using a bbe Fluoroprobe equipped with a $25 \mathrm{~mL}$ cuvette holder. Before pouring the content of the bottles into the cuvette, the bottom of the bottles was gently scraped with a brush to ensure complete resuspension of the benthic algae. Initial biomass was measured in an additional bottle for each species ( 5 and $3 \mu \mathrm{g}$ chl-a. $\mathrm{L}^{-1}$ for $S$. angusta and A. minutissimum, respectively). Diatom growth during the test was assessed by the final biomass (in $\mu \mathrm{g}$ chl- $a . \mathrm{L}^{-1}$ ). Culture samples $(5 \mathrm{~mL})$ were conserved in lugol for organic matter digestion and enumeration of abnormal forms.

As it is often hypothesized that Si limitation may be a cause of diatom frustule deformation, a complementary test was performed to demonstrate that the appearance of abnormal forms in the channel experiment could not be attributed to Si depletion. For this, the species S. angusta was grown in six further bottles. Three of them contained normal growth medium (controls as above) whereas the three others contained filtered river water enriched with all nutrients except silicate. The cultures were carried out in the same conditions as the toxicological tests but for an extended time of 10 days. At the end, diatom biomass in the cultures without $\mathrm{Si}$ addition was $40 \%$ less than in the controls (368 \pm 88 (S.D.) vs. $627 \pm 4 \mu \mathrm{g}$ chl-a. $\mathrm{L}^{-1}$ ) and residual $\mathrm{Si}(\mathrm{OH})_{4}$ concentrations were only $0.18 \pm 0.05$ (S.D.) $\mathrm{mg} \mathrm{SiO}_{2} . \mathrm{L}^{-1}$, which shows that $\mathrm{Si}$ limitation was clearly reached.

\section{Chemical measurements}

\section{Basic parameters}

Two parameters, ash-free dry mass (AFDM) and chlorophyll- $a$, were used as biomass indicators. Biofilm dry mass was determined according to the European standard NF EN 872. AFDM was estimated from the difference between dry mass and final mass after sample combustion in a muffle furnace at $500^{\circ} \mathrm{C}$ for $1 \mathrm{~h}$. Chlorophyll- $a$ content of the biofilm as well as water $\mathrm{pH}$, conductivity and nutrient concentrations were measured following French and international standards (NF T90-117, NF T90-008, NF EN 27888, NF EN ISO 13395, NF EN ISO 11732, NF T90-023 and NF T 90-007).

\section{Metolachlor determination}

For determination of metolachlor concentration, water samples were transferred into $1 \mathrm{~mL}$ vials. An HPLC Ultimate 3000 (Dionex, CA, USA) and with a triple quadrupole mass spectrometer API 2000 (Applied Biosystems, CA, USA) were used. The chromatographic separation was done on a Gemini-NX C18 $3 \mu \mathrm{m}, 110 \AA$, $100 \times 2 \mathrm{~mm}$ equipped with a SecurityGuard from Phenomenex (CA, USA). The two eluents were acetonitrile (A) and ultrapure water with $5 \mathrm{mM}$ ammonium acetate (B), and a linear gradient was applied: an isocratic $10 \%$ mixture of $\mathrm{A}$ for $1 \mathrm{~min}$, then $30 \%$ A till $4 \mathrm{~min}, 40 \%$ A till $8 \mathrm{~min}, 80 \% \mathrm{~A}$ till $9.5 \mathrm{~min}, 80 \%$ isocratic A till $10.5 \mathrm{~min}$, a decrease of $\mathrm{A}$ to $10 \%$ till $11 \mathrm{~min}$ and then the initial composition was maintained for $4 \mathrm{~min}$. The total running time was thus $15 \mathrm{~min}$ and the flow rate was kept constant at $400 \mu \mathrm{L} \cdot \mathrm{min}^{-1}$. Multiple reaction monitoring (MRM) mode was used for the metolachlor with a quantitative transition $(284>252)$ and a second transition for the confirmation $(270>176)$. Metolachlor-d6 $(290>258)$ was used as internal standard.

\section{Diatom microscopic examination}

Biofilm samples were boiled in $\mathrm{H}_{2} \mathrm{O}_{2}$ for $30 \mathrm{~min}$ to oxidize the organic matter. Then the remaining cleaned diatom frustules were transferred to a glass microscope slide in a high-refractive medium (Naphrax $@$, Brunel Microscopes Ltd, UK). Diatom species were identified at $\times 1000$ magnification from the taxonomic literature of Central Europe (Krammer and LangeBertalot, 1986-1991) and recent nomenclature updates. The relative abundance of each species was calculated from a minimum total count of 400 diatom valves.

The bulk proportion of abnormal forms of diatom frustules was estimated separately from a total count 
Table 1. Chemical conditions in the six channels at the start of the experiment $\left(t_{0}\right)$ after 1 and 2 weeks $\left(t_{1}\right.$ and $\left.t_{2}\right)$.

\begin{tabular}{|c|c|c|c|c|c|c|c|}
\hline & $\mathrm{pH}$ & $\begin{array}{l}\text { Conductivity } \\
\left(\mu \mathrm{S} . \mathrm{cm}^{-1}\right)\end{array}$ & $\begin{array}{c}\mathrm{PO}_{4} \\
(\mathrm{mg} \mathrm{P.L}-1)\end{array}$ & $\begin{array}{c}\mathrm{NH}_{4} \\
\left(\mathrm{mg} \mathrm{N} . \mathrm{L}^{-1}\right)\end{array}$ & $\begin{array}{c}\mathrm{NO}_{2} \\
\left(\mathrm{mg} \mathrm{N}^{-1}{ }^{-1}\right) \\
\end{array}$ & $\begin{array}{c}\mathrm{NO}_{3} \\
\left(\mathrm{mg} \mathrm{N}^{-1}{ }^{-1}\right) \\
\end{array}$ & $\begin{array}{c}\mathrm{Si}(\mathrm{OH})_{4} \\
\left(\mathrm{mg} \mathrm{SiO}_{2} \cdot \mathrm{L}^{-1}\right)\end{array}$ \\
\hline \multicolumn{8}{|l|}{$t_{0}$} \\
\hline $0 \mathrm{a}$ & 8.0 & 166 & 0.049 & 0.008 & 0.038 & 1.10 & 4.52 \\
\hline $0 \mathrm{~b}$ & 8.0 & 168 & 0.051 & 0.006 & 0.028 & 1.12 & 4.88 \\
\hline $5 a$ & 8.0 & 170 & 0.049 & 0.004 & 0.036 & 1.07 & 4.88 \\
\hline $5 b$ & 8.0 & 169 & 0.049 & 0.010 & 0.025 & 1.05 & 4.73 \\
\hline $30 \mathrm{a}$ & 8.0 & 170 & 0.051 & 0.005 & 0.036 & 1.04 & 4.27 \\
\hline $30 b$ & 8.0 & 170 & 0.054 & 0.010 & 0.026 & 1.09 & 4.76 \\
\hline \multicolumn{8}{|l|}{$t_{1}$} \\
\hline $0 \mathrm{a}$ & 7.8 & 181 & 0.053 & 0.004 & 0.001 & 1.52 & 5.13 \\
\hline $0 \mathrm{~b}$ & 8.0 & 177 & 0.056 & 0.007 & 0.004 & 1.49 & 5.01 \\
\hline $5 a$ & 8.0 & 185 & 0.046 & 0.010 & 0.000 & 1.59 & 5.28 \\
\hline $5 b$ & 8.0 & 178 & 0.053 & 0.002 & 0.003 & 1.42 & 4.98 \\
\hline $30 \mathrm{a}$ & 8.0 & 178 & 0.048 & 0.000 & 0.003 & 1.35 & 5.11 \\
\hline $30 \mathrm{~b}$ & 8.0 & 174 & 0.049 & 0.003 & 0.002 & 1.24 & 5.08 \\
\hline \multicolumn{8}{|l|}{$t_{2}$} \\
\hline $0 \mathrm{a}$ & 8.1 & 189 & 0.049 & 0.018 & 0.010 & 1.80 & 0.13 \\
\hline $0 \mathrm{~b}$ & 8.2 & 193 & 0.054 & 0.019 & 0.015 & 1.83 & 0.12 \\
\hline $5 a$ & 8.2 & 198 & 0.054 & 0.019 & 0.011 & 1.98 & 0.17 \\
\hline $5 b$ & 8.2 & 194 & 0.058 & 0.019 & 0.010 & 1.84 & 0.12 \\
\hline $30 a$ & 8.2 & 196 & 0.059 & 0.025 & 0.009 & 1.82 & 0.12 \\
\hline $30 \mathrm{~b}$ & 8.2 & 187 & 0.058 & 0.023 & 0.012 & 1.69 & 0.67 \\
\hline
\end{tabular}

of 1000 valves at $\times 2000$ magnification. Only clear morphological deformities of the frustule outline were taken into account (Falasco et al., 2009) excluding irregular striation. The proportion of deformed valves of $S$. angusta was specifically estimated from a mean total count of $75 \pm 39$ (S.D.) valves for the artificial channel samples and among 1000 valves for the monospecific test. In the latter, total cell counts were also performed to establish the linear relationship between chlorophyll- $a$ concentration and cell abundance of $S$. angusta ( $\mu$ g chl- $a=3 \times 10^{-6}$ cell $\left.+3, R^{2}=0.98\right)$.

\section{Statistical analysis}

All statistical analyses were computed using the $\mathrm{R}$ software (Ihaka and Gentleman, 1996). Non-parametric multivariate analysis of variance (NP MANOVA) was used to compare diatom communities among treatments (Anderson, 2001). The analysis was performed on BrayCurtis distances between samples, calculated on logtransformed abundance data of species representing more than $1 \%$ of a community in at least one channel (33 species). Homogeneity of multivariate dispersions within treatments was checked using traditional analysis of variance on residuals after principal coordinate analysis (Anderson, 2006). Two factors were tested in the analysis: the concentration of metolachlor (main factor) and the channel (nested factor: two channels per concentration). Permutations were constrained according to the factor tested. For the nested factor test, permutations of the replicates were done across channels within each contamination level and, for the main factor, channels were permuted across contamination levels keeping pairs of replicates associated with each channel. Nine hundred and ninety-nine permutations of raw data were used for each test. A posteriori pairwise comparisons between treatments were performed with the same permutational test (NP MANOVA) but in a one-way design.

The significance of metolachlor effect on biological parameters (chl- $a$, AFDM, species abundances and abnormal forms) was tested using univariate non-parametric Kruskall-Wallis and Wilcoxon tests.

The Hill model (Hill, 1910) was used to fit the data of the monospecific tests by non-linear regression:

$$
C h l a_{\mathrm{f}}=C h l a_{0}+\frac{\alpha}{1+\left(C_{\mathrm{tox}} / E C_{50}\right)^{\beta}}
$$

where $C h l a_{0}$ and $C h l a_{\mathrm{f}}$ are initial and final diatom biomasses, $C_{\text {tox }}$ is the concentration of the herbicide, $E C_{50}$ is the $50 \%$ effect concentration and $\alpha$ and $\beta$ are other model parameters. The NOEC (no observed effect concentration) was determined by comparing each treatment with control using the one-tailed Wilcoxon test.

\section{Results}

\section{Chemical conditions}

Throughout the experiment $\mathrm{pH}$ and conductivity remained approximately constant (Table 1). Phosphate, which is often the limiting nutrient for algal growth in rivers, was well controlled. Its concentration was low (0.05 mg P. $\left.\mathrm{L}^{-1}\right)$ and similar to natural concentrations in oligotrophic rivers. Ammonium and nitrite had low concentrations and only slight opposite variations. Nitrate increased from about 1 to almost $2 \mathrm{mg} \mathrm{N} . \mathrm{L}^{-1}$, whereas silicic acid concentrations fell during the last week in a comparable way in each channel. Overall, in spite of variations of some nutrients over time, for one given time, there was only little difference between treatments. 


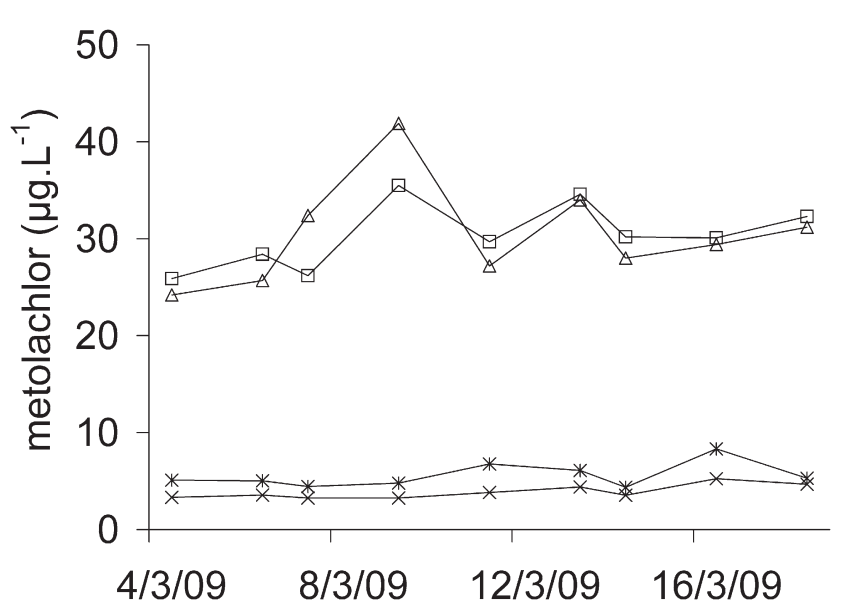

Fig. 1. Concentrations of metolachlor in the four contaminated channels (channels 5a, 5b and 30a, 30b) along the duration of the experiment.

Metolachlor concentrations varied only moderately and maintained values close to the nominal concentrations fixed at 5 and $30 \mu \mathrm{g} . \mathrm{L}^{-1}$ (Fig. 1). Time-weighted average concentrations were $5.7 \pm 1.1,3.9 \pm 0.9,30.9 \pm 4.8$ and $30.6 \pm 4.1 \mu \mathrm{g} . \mathrm{L}^{-1}$ ( \pm S.D.) for channels $5 \mathrm{a}, 5 \mathrm{~b}, 30 \mathrm{a}$ and $30 \mathrm{~b}$, respectively. The herbicide was not detected in the control channels.

\section{Effect on biomass}

The growth of biofilm on the glass slides in the artificial channels was assessed through the two biomass indicators: AFDM and chl- $a$. Final biomass did not differ significantly between treatments (Fig. 2) as regards both indicators, and thus no effect of metolachlor was apparent on periphyton biomass. Chl- $a$ density and AFDM reached on average $0.04 \mathrm{mg} . \mathrm{cm}^{-2}$ and $0.04 \mathrm{mg} . \mathrm{dm}^{-2}$, respectively, at the end of the experiment.

The monospecific toxicological tests showed no apparent effect of metolachlor on diatom growth at concentrations under $100 \mu \mathrm{g} . \mathrm{L}^{-1} . E C_{50}$ values were estimated at 2962 and $1880 \mu \mathrm{g} . \mathrm{L}^{-1}$ metolachlor for S. angusta and A. minutissimum, respectively (Fig. 3). The NOEC amounted to $180 \mu \mathrm{g} . \mathrm{L}^{-1}$ for both species.

\section{Effect on community composition}

The dominant species of diatom communities sampled at the end of the channel experiment are presented in Table 2. The communities were characterized by the predominance of small species (Nitzschia pusilla, Eolimna minima, Planothidium frequentissimum, Mayamaea permitis and Navicula seminulum) and by the relative importance of the centric Melosira varians and some larger species from the genus Nitzschia (Nitzschia palea and Nitzschia gracilis) and Surirella (Surirella angusta and Surirella brebissonii).

The application of non-parametric multivariate ANOVA revealed a significant effect of metolachlor on diatom community composition $(p=0.016)$ and the

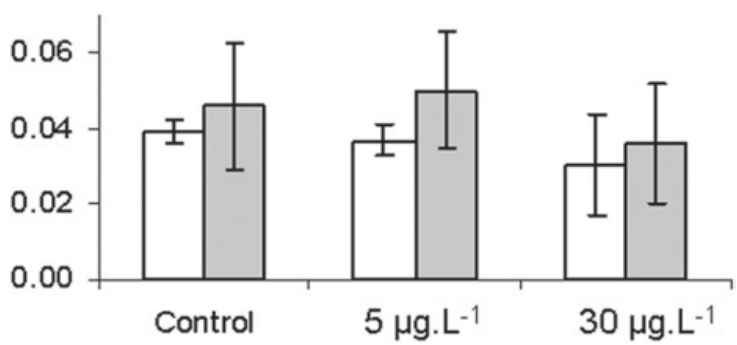

Fig. 2. Biofilm biomass $( \pm$ S.E.) on glass slides after 14 days of experiment, expressed as ash-free dry mass (AFDM, white bars, $\mathrm{mg} . \mathrm{cm}^{-2}$ ) and as chlorophyll- $a$ (grey bars, mg.dm ${ }^{-2}$ ).

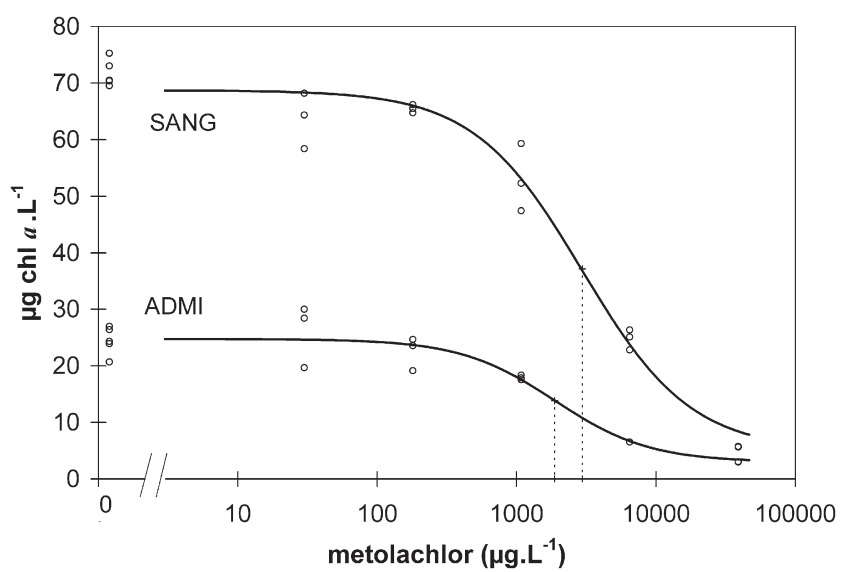

Fig. 3. Results of the acute toxicity tests of metolachlor based on growth inhibition of the diatoms Surirella angusta (SANG) and Achnanthidium minutissimum (ADMI). The graph presents diatom biomass (in $\mu \mathrm{g} \mathrm{chl}-a . \mathrm{L}^{-1}$ ) at the end of the tests. Vertical dashed lines indicate $E C_{50}$ values.

absence of a channel effect ( $p=0.108$ ) (Table 3). Pairwise comparisons between treatments indicated that most of the difference lay between control channels and the contaminated ones ( 5 and $30 \mu \mathrm{g} . \mathrm{L}^{-1}$ ) that did not significantly differ from each other (Table 2 and Fig. 4).

Individual variations in the relative abundance of some species among treatments can suggest sensitivity or tolerance. The species Achnanthidium minutissimum, Mayamaea permitis, Nitzschia palea and to a lesser extent $N$. pusilla had lower abundance at high contamination levels (Fig. 5) and may be considered sensitive to metolachlor. Other species increased in abundance with metolachlor concentration and therefore appeared rather tolerant, especially Planothidium frequentissimum, P. lanceolatum, Surirella brebissonii, Amphora montana and Nitzschia gracilis.

\section{Abnormal forms}

A higher proportion of abnormal forms of diatom frustules was observed in the contaminated channels (Fig. 6). In whole communities, it remained very low $(<6 \%$, Fig. 7). Nevertheless the increase with metolachlor concentration was significant. Deformities were particularly prominent in the sub-dominant species Surirella angusta 


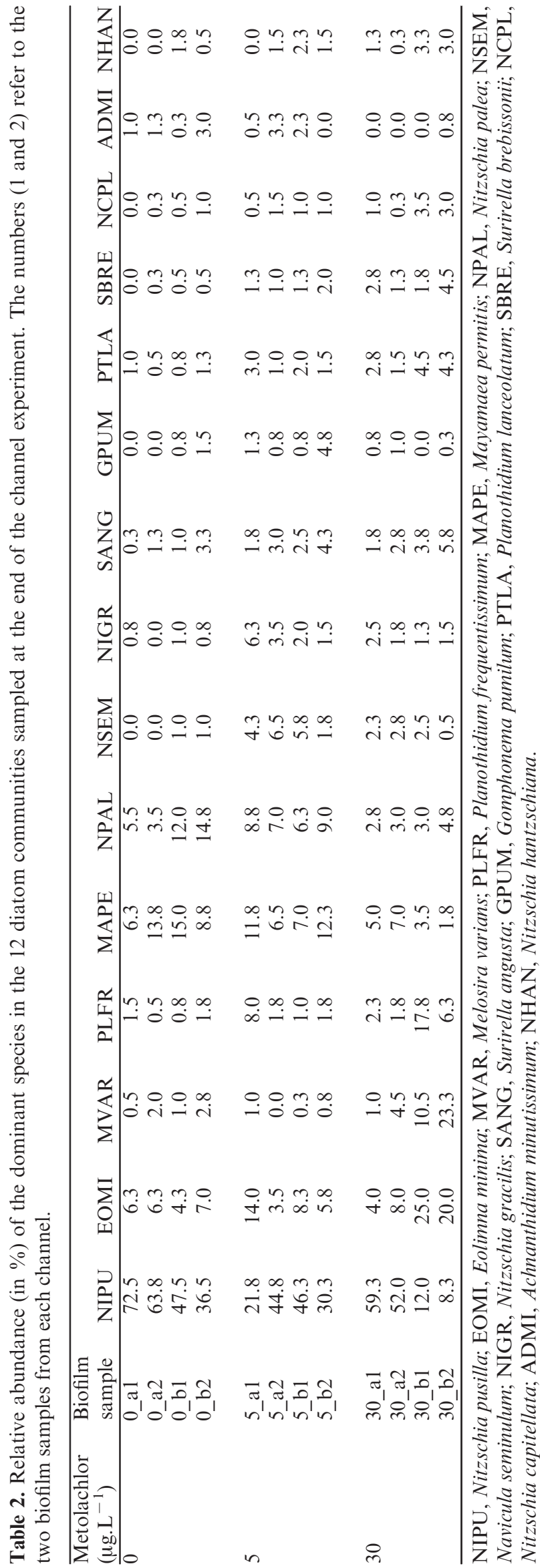

Table 3. Results of non-parametric multivariate ANOVA applied on diatom community samples.

\begin{tabular}{|c|c|c|c|c|}
\hline NP MANOVA & $\mathrm{df}$ & MS & $F$ & $p$ Value \\
\hline Metolachlor & 2 & 0.10613 & 2.145427 & $0.016^{*}$ \\
\hline Microcosm (nested) & 3 & 0.04947 & 1.839264 & 0.108 \\
\hline Residuals & 6 & 0.02690 & & \\
\hline \multicolumn{5}{|c|}{ Pairwise comparisons among treatments } \\
\hline Control vs. $5 \mu \mathrm{g} . \mathrm{L}^{-1}$ & 1 & 0.098363 & 3.1254 & $0.028^{*}$ \\
\hline Residuals & 6 & 0.031472 & & \\
\hline Control vs. $30 \mu \mathrm{g} . \mathrm{L}^{-1}$ & 1 & 0.131271 & 3.4224 & $0.028 *$ \\
\hline Residuals & 6 & 0.038357 & & \\
\hline 5 ug. $\mathrm{L}^{-1} v s .30 \mu \mathrm{g} . \mathrm{L}^{-1}$ & 1 & 0.088753 & 2.6549 & 0.058 \\
\hline Residuals & 6 & 0.033429 & & \\
\hline
\end{tabular}

*Significant results $(\alpha=0.05)$.

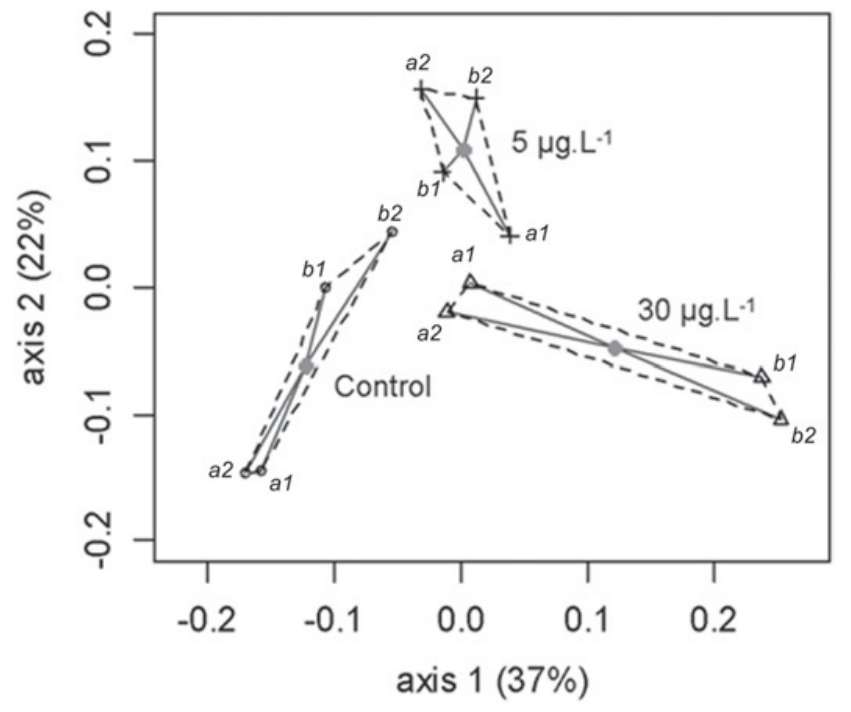

Fig. 4. Principal coordinate plot of diatom communities at the end of the channel experiment derived from Bray-Curtis distances between samples. Sample dispersion around their centroid was not significantly different among treatments (ANOVA, $p=0.15$ ). The letters ( $\mathrm{a}$ and $\mathrm{b}$ ) and the numbers (1 and 2) refer to the duplicate channels and to the two biofilm samples collected in each channel, respectively.

(Fig. 6). Their frequency in the populations of S. angusta increased significantly with contamination to reach $80 \%$ at the end of the experiment at $30 \mu \mathrm{g} . \mathrm{L}^{-1}$ (Fig. 7).

In the monospecific cultures of S. angusta, abnormal valves were approximately 2-fold more abundant in the presence of metolachlor but no dose effect was evidenced after four days exposure. Si-limited cultures exhibited significantly less abnormal forms than contaminated cultures and did not differ from controls in this aspect (Fig. 8).

\section{Discussion}

\section{Structural vs. quantitative endpoints}

The channel experiment demonstrated an effect of metolachlor from a concentration of $5 \mu \mathrm{g} . \mathrm{L}^{-1}$ on the 


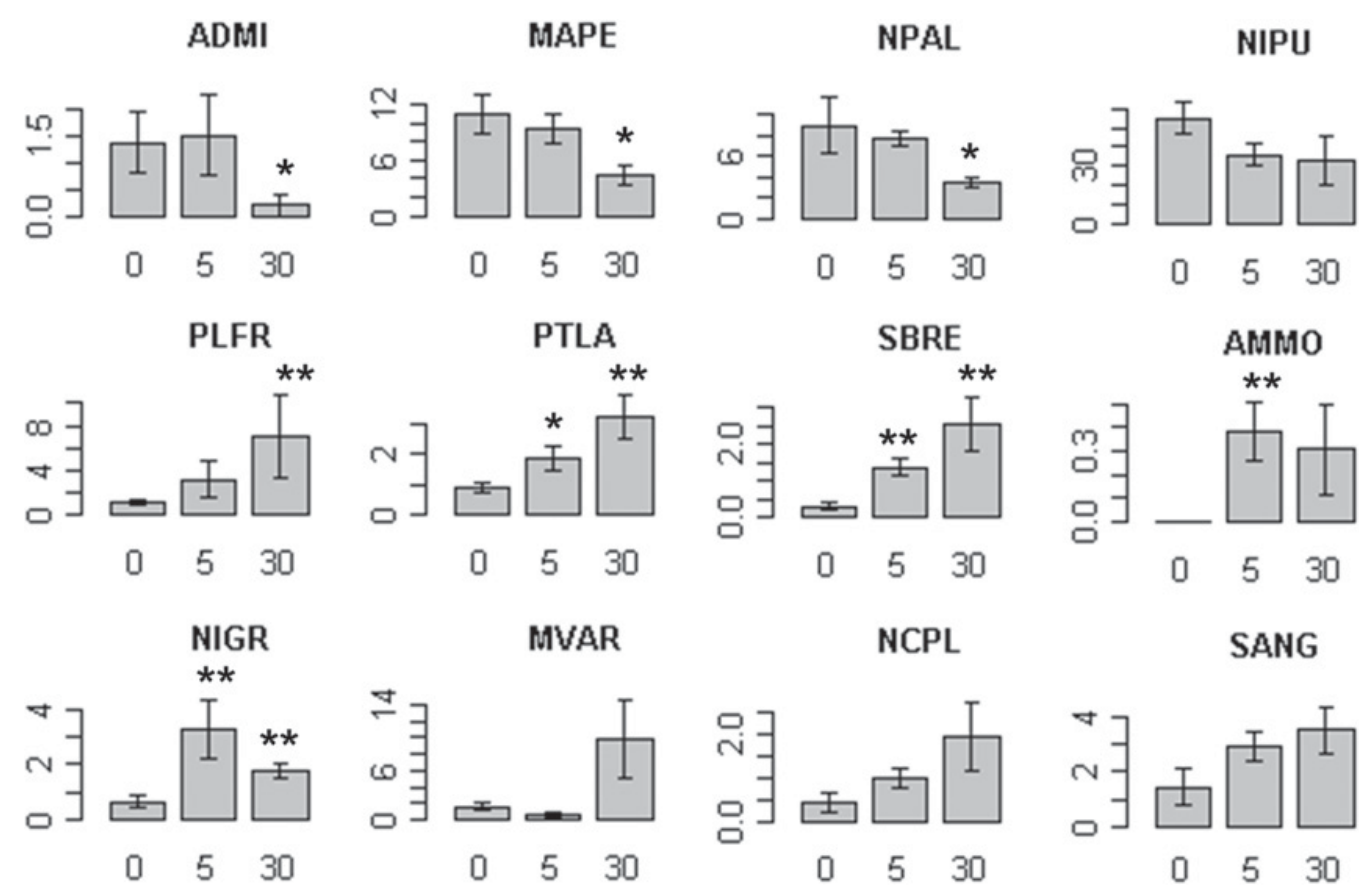

Fig. 5. Bar plots of the relative abundance (in $\%, \pm$ S.E.) of some diatom species suggesting sensitivity or tolerance to metolachlor. Differences with control conditions were investigated using Wilcoxon's test $\left({ }^{*} p<0.1,{ }^{* *} p<0.05\right)$. ADMI, Achnanthidium minutissimum; MAPE, Mayamaea permitis; NPAL, Nitzschia palea; NIPU, Nitzschia pusillana; PLFR, Planothidium frequentissimum; PTLA, Planothidium lanceolatum; SBRE, Surirella brebissonii; AMMO, Amphora montana; NIGR, Nitzschia gracilis; MVAR, Melosira varians; NCPL, Nitzschia capitellata; SANG, Surirella angusta.

species composition of diatom assemblages after two weeks of substrate colonization. This effect was revealed by maintaining the contamination level and all other factors that influence diatom communities, namely light, trophic level and current velocity. Starting from realistic oligotrophic conditions, the regular addition of nutrients allowed biofilm growth on the substrates but could not prevent transient $\mathrm{Si}$ limitation at the end of the experiment. Indeed as biomass accumulates exponentially, the consumption of nutrient increases accordingly and the frequency of nutrient supply should have been increased likewise. Nevertheless Si limitation occurred similarly in each channel only at the end of the experiment and may not have differentially influenced the effect of the herbicide on diatom community composition.

These results obtained under controlled conditions confirm that the diatom community alterations observed in the field can be the consequence of chronic river contamination by herbicides (Morin et al., 2009; Roubeix et al., 2010). Here, the demonstration of the toxic effect of metolachlor on river diatom community composition at environmental contamination levels is clearly evidenced. The relatively low difference between communities formed at 5 and $30 \mu \mathrm{g} . \mathrm{L}^{-1}$ of metolachlor suggests that most of the difference from control already lay in the communities at $5 \mu \mathrm{g} . \mathrm{L}^{-1}$ and that the effect of the toxicant might be visible at even lower concentrations.

However, descriptors related to periphyton biomass (chl- $a$ and AFDM) did not indicate any effect of metolachlor at the tested concentrations. Moreover, $E C_{50}$ values from the monospecific tests and from other similar studies with microalgae based on short-term growth inhibition tests (Junghans et al., 2003; Vallotton et al., 2008; Liu and Xiong, 2009) suggest much higher effect thresholds. Indeed, no significant effect of metolachlor was visible on the growth of $S$. angusta and A. minutissimum up to a concentration of $180 \mu \mathrm{g} . \mathrm{L}^{-1}$ (NOEC). As tolerant species progressively replace sensitive ones in a community exposed to a toxicant, the effect on the whole community biomass may not be visible unless the tolerance limit of the most robust and competitive species is reached. Therefore community composition change is a more sensitive endpoint to evaluate the toxicity of a pollutant on a natural aquatic environment and deviation from the reference condition, as requested by the European Water Framework Directive.

\section{Species sensitive/tolerant to metolachlor}

The changes in composition of diatom communities with metolachlor concentrations are informative about the possible bioindication of herbicide contamination. In such microcosm experiments, the decrease in abundance of a species along a contamination gradient may result from species sensitivity to the tested toxicant or to a change in biological interactions linked to water toxicity. Achnanthidium minutissimum is a species indicative of good water quality (Coste et al., 2009), which was shown (as in this study) to maintain its relative abundance at low 

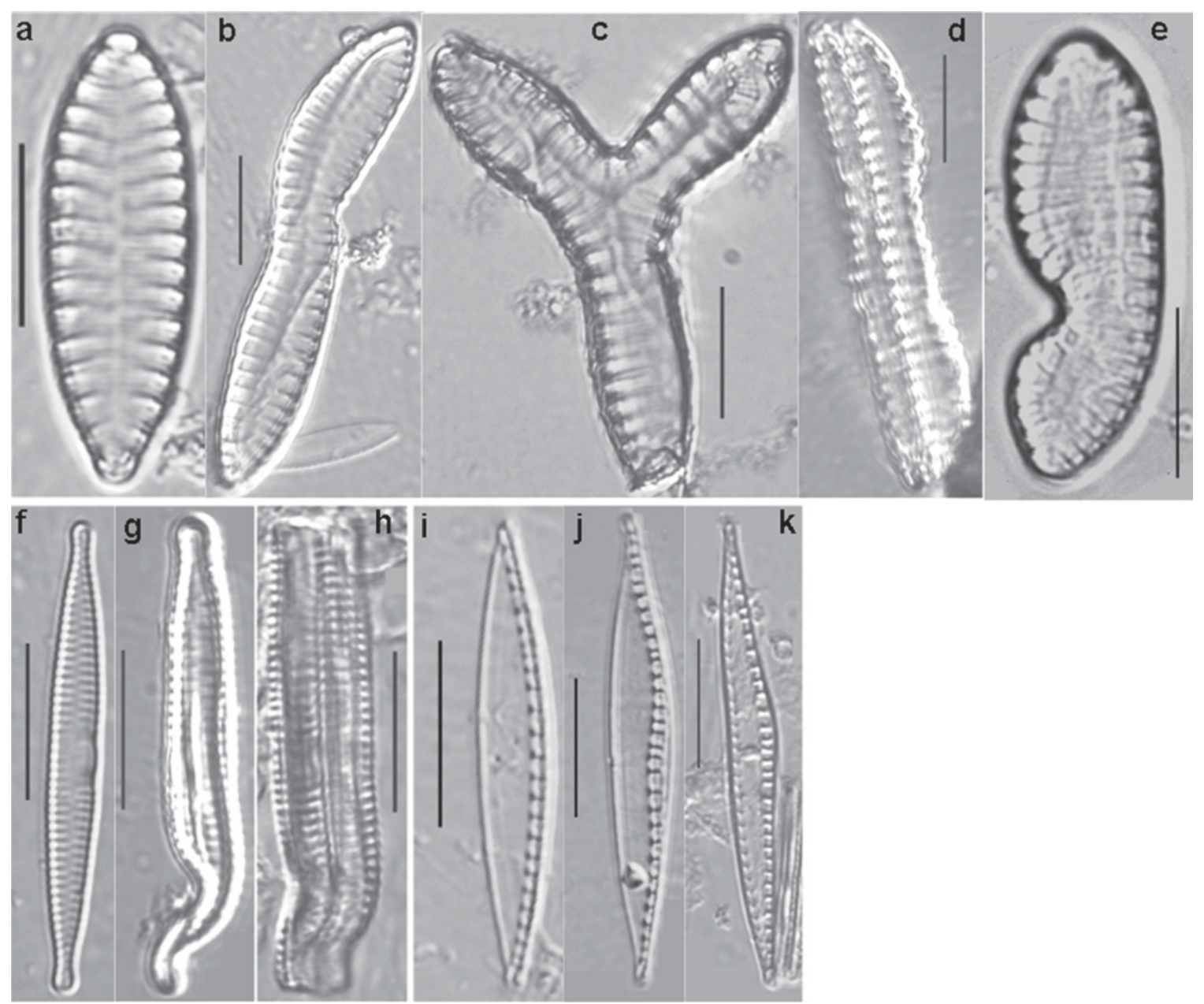

Fig. 6. Abnormal diatom frustules observed in the contaminated experimental units for the species Surirella angusta (a to e), Fragilaria capucina (f to h) and Nitzschia sociabilis (i to k). (a), (f) and (i): normal form of each species; (d) and (h): pair of deformed frustules following vegetative reproduction $(\mathrm{OM} \times 1000$, vertical bars indicate $10 \mu \mathrm{m})$.
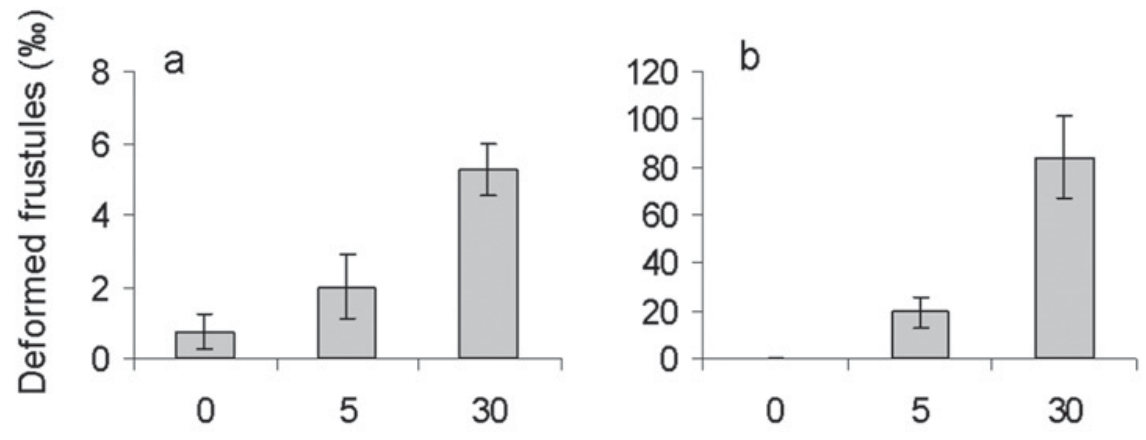

Metolachlor concentration $\left(\mu \mathrm{g} . \mathrm{L}^{-1}\right)$

Fig. 7. Relative abundance of deformed frustules ( \pm S.E.) in the whole diatom community (a) and within Surirella angusta populations (b). Kruskall-Wallis test: $p<0.05$ (a) and $p<0.01$ (b).

herbicide concentration and to be strongly reduced at higher contamination levels (Hamilton et al., 1987; Pérès et al., 1996). Therefore, it seems that $A$. minutissimum is rather sensitive to herbicides. This is supported by the lower $E C_{50}$ obtained for this species than for $S$. angusta, which appeared indifferent to metolachlor in the channel experiment. The species Mayamaea permitis and Nitzschia palea may bring interesting information for separating toxic vs. trophic effects, as they exhibited the same sensitivity pattern as A. minutissimum (Fig. 5); however, 


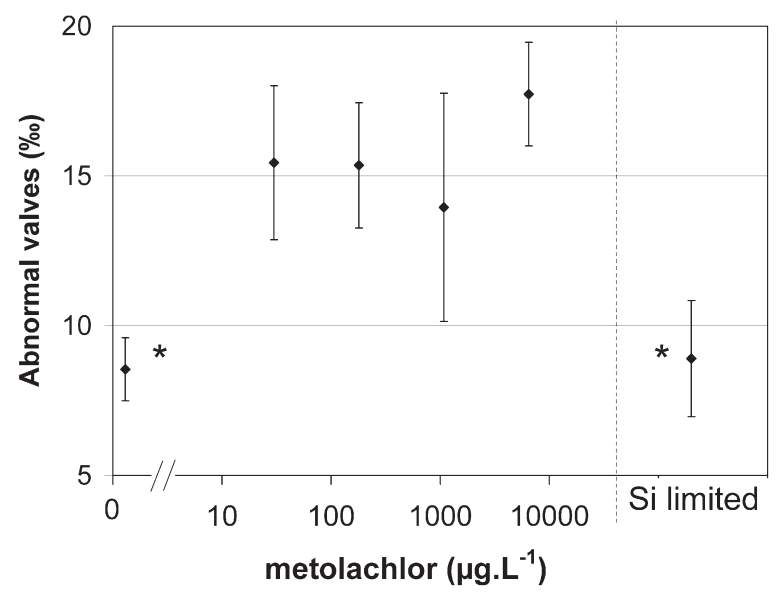

Fig. 8. Variations in the proportion of abnormal valves of the species Surirella angusta in relation to metolachlor concentration and $\mathrm{Si}$ limitation. Results from the acute toxicity test (*significantly different from contaminated cultures, $p<0.05$, Wilcoxon test).

they are known to be generally more tolerant to organic and trophic pollution. The species Nitzschia pusilla had a lower relative abundance in the two treatments with metolachlor. However, it remained the dominant species in almost all communities sampled. It may be rather indifferent to metolachlor and the drop in relative abundance would result from the greater development of tolerant species in contaminated channels.

Species increasing their proportion in communities formed at higher metolachlor concentrations may be considered tolerant. This is the case of the saprophilous Surirella brebissonii as well as $P$. frequentissimum and $P$. lanceolatum, which have already been identified as tolerant to pollution by herbicides including metolachlor in a previous field approach (Roubeix et al., 2010). A. montana, $N$. gracilis and especially $N$. capitellata are characteristic of low water quality (Coste et al., 2009) and showed tolerance to metolachlor in this study. For $M$. varians, however, general knowledge of its sensitivity to pollution (eutrophication and saproby) is not consistent with the findings of certain herbicide studies. Indeed $M$. varians is generally recorded in clean rivers but appears to accommodate well to high herbicide concentrations (Spawn et al., 1997; Debenest et al., 2009).

\section{Relevance of abnormal forms as an indication of toxicity}

This experimental study clearly establishes the link between abnormal forms and the herbicide. The appearance of diatom deformities is often presumed to result from Si limitation (Debenest et al., 2010). However, from this study, this hypothesis can be rejected for several reasons: (1) there was a clear dose effect in the channels and there was most $\mathrm{Si}$ left in one of the most contaminated channels (30b); (2) in the monospecific test, deformities were significantly more abundant in the contaminated cultures; and (3) Si limitation did not produce more abnormal forms than control conditions. The duration of the experiments (14 vs. 4 days) may be the cause of the difference in proportion and in response to concentration between the channel experiment and the monospecific test. It is likely that the proportion of abnormal forms in a population increases with time at a rate depending on the exposure level. It could also be hypothesized that the progressive degradation of metolachlor may produce metabolites having higher teratogenic effects than metolachlor (Osano et al., 2002; Hladik et al., 2005).

Like other herbicides belonging to the chloroacetanilide class, metolachlor inhibits the biosynthesis of very long chain fatty acids in plants and microalgae (Boger et al., 2000) and consequently blocks cell division and enlargement. Such a mode of action does not a priori suggest an effect on diatom frustule structure. However, changes in ultrastructural morphology were reported in a green microalgae following exposure to metolachlor (Liu and Xiong, 2009). As the synthesis of the diatom frustule involves a special intracellular vesicle (SDV) and requires the exocytosis of biogenic silica (Martin-Jezequel et al., 2000), any alteration of the cell membrane system may have repercussions on frustule construction.

The link between abnormal diatom forms and contamination by heavy metals has been well documented (Gold et al., 2003; Cattaneo et al., 2004; Morin et al., 2008; Falasco et al., 2009). However, the literature on the effect of herbicides on diatom morphology is scarce. There are now experimental studies reporting diatom deformities due to herbicides with three different physiological targets: photosynthesis (isoproturon), gene expression (maleic hydrazide) and lipid synthesis (metolachlor, this study) (Schmitt-Jansen and Altenburger, 2005; Debenest et al., 2008). The variety of toxicants giving the same effect on diatoms suggests that toxic stress generally generates abnormal forms.

The frequency of abnormal forms has already been proposed as a bioindicator of heavy metal contamination (Cattaneo et al., 2004). Recent results concerning the effects of herbicides suggest that abnormal forms might also be used to indicate herbicide contamination in the field. However, as the relative abundance of deformities is generally just a few \%o (Fig. 7) (Morin et al., 2009), this would require a higher counting effort than bioindication on a taxonomic basis (AFNOR, 2004). The example of $S$. angusta shows that it would be easier to focus on widespread sensitive species that could be used as sentinels.

\section{Conclusion}

The experiments conducted in this study showed that metolachlor has toxic effects on river periphytic diatoms. The results are interesting for the toxicological assessment of pesticides as well as for the bioindication of contamination. It emerges that effect concentrations may vary according to the species and the endpoint (biomass, 
deformities and community composition) considered. Microalgal tests based on biomass can be easily related to ecosystem functions (primary production and trophic pathways). However, diatom community composition seems to be more sensitive to contamination and should be considered as a relevant endpoint. Also the channel experiment provided information about the tolerance of some diatom species to metolachlor. These data will contribute to the knowledge of diatom sensitivity to toxicants, which could lead to the construction of new diatom indices of water quality. Our experimental results support the inclusion of abnormal diatom forms in water quality indices because they may reflect toxic stress.

Acknowledgements. We thank Sylvia Moreira for help in the field and Maryse Boudigues, Muriel Bonnet and Brigitte Delest for the chemical analysis of the samples. We are also grateful to the two anonymous reviewers whose comments were very useful for the improvement of the manuscript.

\section{References}

AFNOR, 2004. Qualité de l'eau - Guide pour l'identification et le dénombrement des échantillons de diatomées benthiques de rivières, et leur interprétation. Norme NF EN ISO 14407 (October 2004), T90-357-2, 12 p.

Anderson M.J., 2001. A new method for non-parametric multivariate analysis of variance. Austral. Ecol., 26, 32-46.

Anderson M.J., 2006. Distance-based tests for homogeneity of multivariate dispersions. Biometrics, 62, 245-253.

Battaglin W.A., Furlong E.T., Burkhardt M.R. and Peter C.J., 2000. Occurrence of sulfonylurea, sulfonamide, imidazolinone, and other herbicides in rivers, reservoirs and ground water in the Midwestern United States, 1998. Sci. Total Environ., 248, 123-133.

Boger P., Matthes B. and Schmalfuss J., 2000. Towards the primary target of chloroacetamides - new findings pave the way. Pest Manag. Sci., 56, 497-508.

Cattaneo A., Couillard Y., Wunsam S. and Courcelles M., 2004. Diatom taxonomic and morphological changes as indicators of metal pollution and recovery in Lac Dufault (Quebec, Canada). J. Paleolimnol., 32, 163-175.

Clark G.M. and Goolsby D.A., 2000. Occurrence and load of selected herbicides and metabolites in the lower Mississippi River. Sci. Total Environ., 248, 101-113.

Coste M., Boutry S., Tison-Rosebery J. and Delmas F., 2009. Improvements of the Biological Diatom Index (BDI): Description and efficiency of the new version (BDI-2006). Ecol. Indic., 9, 621-650.

Debenest T., Silvestre J., Coste M., Delmas F. and Pinelli E., 2008. Herbicide effects on freshwater benthic diatoms: Induction of nucleus alterations and silica cell wall abnormalities. Aquat. Toxicol., 88, 88-94.

Debenest T., Pinelli E., Coste M., Silvestre J., Mazzella N., Madigou C. and Delmas F., 2009. Sensitivity of freshwater periphytic diatoms to agricultural herbicides. Aquat. Toxicol., 93, 11-17.

Debenest T., Silvestre J., Coste M. and Pinelli E., 2010. Effects of pesticides on freshwater diatoms. Rev. Environ. Contam. Toxicol., 203, 87-103.
Dubois A., Lacouture L. and Feuillet C., 2010. Les pesticides dans les milieux aquatiques, Études et Documents, 26, Commissariat Général au Développement Durable, Paris.

European Commission, 2000. Directive 2000/60/EC of the European parliament and of the council of 23rd October 2000 establishing a framework for community action in the field of water policy. Off. J. Eur. Commun., 327, 1-72.

Fairchild J.F., Ruessler D.S., Haverland P.S. and Carlson A.R., 1997. Comparative sensitivity of Selenastrum capricornutum and Lemna minor to sixteen herbicides. Arch. Environ. Con. Toxicol., 32, 353-357.

Falasco E., Bona F., Ginepro M., Hlubikova D., Hoffmann L. and Ector L., 2009. Morphological abnormalities of diatom silica walls in relation to heavy metal contamination and artificial growth conditions. Water SA, 35, 595-606.

Gold C., Feurtet-Mazel A., Coste M. and Boudou A., 2003. Effects of cadmium stress on periphytic diatom communities in indoor artificial streams. Freshwater Biol., 48, 316-328.

Guillard R.R.L. and Lorenzen C.J., 1972. Yellow-green algae with chlorophyllide c. J. Phycol., 8, 10-14.

Hamala J.A. and Kollig H.P., 1985. The effects of atrazine on periphyton communities in controlled laboratory ecosystems. Chemosphere, 14, 1391-1408.

Hamilton P.B., Jackson G.S., Kaushik N.K. and Solomon K.R., 1987. The impact of atrazine on lake periphyton communities, including carbon uptake dynamics using track autoradiography. Environ. Pollut., 46, 83-103.

Hering D., Borja A., Carstensen J., Carvalho L., Elliott M., Feld C.K., Heiskanen A.S., Johnson R.K., Moe J., Pont D., Solheim A.L. and de Bund W.V., 2010. The European Water Framework Directive at the age of 10: A critical review of the achievements with recommendations for the future. Sci. Total Environ., 408, 4007-4019.

Hill A.V., 1910. The possible effects of the aggregation of the molecules of hæmoglobin on its dissociation curves. $J$. Physiol., 40 (Suppl.), iv-vii.

Hladik M.L., Hsiao J.J. and Roberts A.L., 2005. Are neutral chloroacetamide herbicide degradates of potential environmental concern? Analysis and occurrence in the Upper Chesapeake Bay. Environ. Sci. Technol., 39, 6561-6574.

Ihaka R. and Gentleman R., 1996. R: A language for data analysis and graphics. J. Comput. Graph. Stat., 5, 299-314.

Ivorra N., Barranguet C., Jonker M., Kraak M.H.S. and Admiraal W., 2002. Metal-induced tolerance in the freshwater microbenthic diatom Gomphonema parvulum. Environ. Pollut., 116, 147-157.

Junghans M., Backhaus T., Faust M., Scholze M. and Grimme L.H., 2003. Predictability of combined effects of eight chloroacetanilide herbicides on algal reproduction. Pest. Manag. Sci., 59, 1101-1110.

Kegley S.E., Hill B.R., Orme S. and Choi A.H., 2010. PAN pesticide database, Pesticide Action Network, San Francisco.

Kosinski R.J., 1984. The effect of terrestrial herbicides on the community structure of stream periphyton. Environ. Pollut. A, 36, 165-189.

Krammer K. and Lange-Bertalot H., 1986-1991. Bacillariophyceae 1. Teil: Naviculaceae, 876 p.; 2. Teil: Bacillariaceae, Epithemiaceae, Surirellaceae, 596 p.; 3. Teil: Centrales, Fragilariaceae, Eunotiaceae, 576 p.; 4. Teil: Achnanthaceae. Kritische Ergänzungen zu Navicula (Lineolatae) und Gomphonema, G. Fischer Verlag, Stuttgart, $437 \mathrm{p}$. 
Liu H. and Xiong M., 2009. Comparative toxicity of racemic metolachlor and S-metolachlor to Chlorella pyrenoidosa. Aquat. Toxicol., 93, 100-106.

Ma J. and Liang W., 2001. Acute toxicity of 12 herbicides to the green algae Chlorella pyrenoidosa and Scenedesmus obliquus. Bull. Environ. Contam. Toxicol., 67, 347-351.

Ma J., Lin F., Wang S. and Xu L., 2003. Toxicity of 21 herbicides to the green alga Scenedesmus quadricauda. Bull. Environ. Contam. Toxicol., 71, 594-601.

Martin-Jezequel V., Hildebrand M. and Brzezinski M.A., 2000. Silicon metabolism in diatoms: Implications for growth. J. Phycol., 36, 821-840.

Mohr S., Feibicke M., Berghahn R., Schmiediche R. and Schmidt R., 2008. Response of plankton communities in freshwater pond and stream mesocosms to the herbicide metazachlor. Environ. Pollut., 152, 530-542.

Morin S., Duong T.T., Dabrin A., Coynel A., Herlory O., Baudrimont M., Delmas F., Durrieu G., Schafer J., Winterton P., Blanc G. and Coste M., 2008. Long-term survey of heavy-metal pollution, biofilm contamination and diatom community structure in the Riou Mort watershed, South-West France. Environ. Pollut., 151, 532-542.

Morin S., Bottin M., Mazzella N., Macary F., Delmas F., Winterton P. and Coste M., 2009. Linking diatom community structure to pesticide input as evaluated through a spatial contamination potential (Phytopixal): A case study in the Neste river system (South-West France). Aquat. Toxicol., 94, 28-39.

Noack U., Geffke T., Balasubramanian R., Papenbrock J., Braunec M. and Scheerbaum D., 2003. Effects of the herbicide metazachlor on phytoplankton and periphyton communities in outdoor mesocosms. Acta Hydrochim. Hydrobiol., 31, 482-490.

Osano O., Admiraal W., Klamer H.J.C., Pastor D. and Bleeker E.A.J., 2002. Comparative toxic and genotoxic effects of chloroacetanilides, formamidines and their degradation products on Vibrio fischeri and Chironomus riparius. Environ. Pollut., 119, 195-202.

Pérès F., Florin D., Grollier T., Feurtet-Mazel A., Coste M., Ribeyre F., Ricard M. and Boudou A., 1996. Effects of the phenylurea herbicide isoproturon on periphytic diatom communities in freshwater indoor microcosms. Environ. Pollut., 94, 141-152.

Pesce S., Lissalde S., Lavieille D., Margoum C., Mazzella N., Roubeix V. and Montuelle B., 2010. Evaluation of single and joint toxic effects of diuron and its main metabolites on natural phototrophic biofilms using a pollution-induced community tolerance (PICT) approach. Aquat. Toxicol., 99, 492-499.

Prygiel J., Coste M. and Bukowska J., 1999. Review of the major diatom-based techniques for the quality assessment of rivers - State of the art in Europe. In: Prygiel J., Whitton B.A. and Bukowska J. (eds.), Use of algae for monitoring rivers III, Agence de l'Eau Artois-Picardie, Douai, 224-238.

Ricart M., Barceló D., Geiszinger A., Guasch H., Alda M.L.D., Romaní A.M., Vidal G., Villagrasa M. and Sabater S., 2009. Effects of low concentrations of the phenylurea herbicide diuron on biofilm algae and bacteria. Chemosphere, 76, 1392-1401.

Roubeix V., Mazzella N., Delmas F. and Coste M., 2010. In situ evaluation of herbicide effects on the composition of river periphytic diatom communities in a region of intensive agriculture. Vie Milieu, 160, 233-241.

Schmitt-Jansen M. and Altenburger R., 2005. Toxic effects of isoproturon on periphyton communities - a microcosm study. Estuar. Coast. Shelf Sci., 62, 539-545.

Spawn R.L., Hoagland K.D. and Siegfried B.D., 1997. Effects of alachlor on an algal community from a midwestern agricultural stream. Environ. Toxicol. Chem., 16, 785-793.

Vallotton N., Moser D., Eggen R.I.L., Junghans M. and Chèvre N., 2008. S-metolachlor pulse exposure on the alga Scenedesmus vacuolatus: Effects during exposure and the subsequent recovery. Chemosphere, 73, 395-400.

Vera M.S., Lagomarsino L., Sylvester M., Perez G.L., Rodriguez P., Mugni H., Sinistro R., Ferraro M., Bonetto C., Zagarese H. and Pizarro H., 2010. New evidences of Roundup ${ }^{\circledR}$ (glyphosate formulation) impact on the periphyton community and the water quality of freshwater ecosystems. Ecotoxicology, 19, 710-721. 